\title{
Developing Foreign Language Literacy Skills in Primary School
}

\author{
Mateja Dagarin Fojkar \\ Faculty of Education, University of Ljubljana, Slovenia \\ mateja.dagarin@pef.uni-lj.si \\ Mira Metljak \\ Faculty of Education, University of Ljubljana, Slovenia \\ mira.metljak@pef.uni-lj.si
}

\author{
Tina Rozmanič \\ Faculty of Education, University of Ljubljana, Slovenia \\ tina.rozmanic@pef.uni-lj.si
}

\begin{abstract}
Literacy impacts many social, economic and cultural areas of human life. In its broad definition, it entails the development of language; however, its traditional interpretation is the ability to read and write. In the school context, its development spreads across the whole curriculum, with its subskills influencing each other. Reading is reported to be the least developed English language skill of Slovenian students in the ninth grade of primary school. This suggests that there may be clear benefits in starting its development earlier and in a more systematic way. The aim of the present research was to investigate how English teachers $(N=111)$ develop foreign language literacy skills in grades 3-5 in Slovenian primary schools. A questionnaire was constructed for this purpose, exploring teachers' practices in developing English reading and writing skills as well as the strategies, activities and materials they use for developing their students' literacy skills. The research results will serve as guidance in creating foreign language literacy materials and training programmes for teachers.
\end{abstract}

Keywords: young learners, literacy, foreign language, teachers' practices

\section{Introduction}

The area of literacy development has seen many changes in recent years. The traditional definition of literacy as 'developing reading and writing skills' was later extended to a competence that 'involves the ability to interpret and critically evaluate a wide variety of written and spoken texts' (Kern 2000,3), including visual literacy, i.e. skills involved in interpreting and producing visual content (Ediger 2014). In response to the present-day technological development, Leu et al. $(2007,38)$ have defined literacy as 'the ability to find, identify, evaluate, use and communicate using a variety of resources, including text, 
visual, audio and video.' At its core it is the ability to communicate in various cultural contexts and shifting the focus 'from "what texts mean" to what people mean by texts, and what texts mean to people...' (Kern 2000, 2).

In Slovenia, the learning of the first foreign language (FL) as a compulsory subject in the second year of primary education was introduced in 2016, which means that more time can be dedicated to the development of initial foreign language literacy skills. This is encouraging, since the results of the Surveylang report in 2012 showed that reading was the least developed skill of Slovenian students in the ninth grade, with $12 \%$ of students failing to achieve even the first reference level, i.e. A1 (European Commission 2012, 42). Starting with literacy development early on can expedite its development and make English learners competent readers and users of language.

Considering the recent changes in the literacy definitions and low results of Slovenian students' reading skills in the Surveylang report, our aim was to investigate teachers' practices in developing reading and writing skills at the stage when students are, according to Baker (2001), at the peak of developing their literacy skills, in the first years of primary school. We explored the activities and materials teachers use for developing their students' literacy skills, the strategies they develop in their students' reading skills and the classroom management they apply in developing literacy skills in their lessons. In the conclusion, recommendations and guidelines for a more systematic approach to developing FL literacy skills are put forward.

\section{Developing Foreign Language Literacy}

Literacy is an ever-changing and developing phenomenon and as such has undergone many different phases. Stevenson (2018) divides the notion of literacy into three theoretical paradigms. The first one is the textual paradigm in which literacy is part of the language and entails grammar, lexis and genres, and in which learning to read and write is about understanding different genres. The second paradigm is the process paradigm in which learners employ different strategies and processes in developing their reading and writing skills. The third paradigm, which has recently gained importance, is the social paradigm in which learning to read and write is seen as understanding the expectations and practices in different social and cultural contexts.

In its broad definition literacy does not relate only to the development of reading and writing skills; it is an all-encompassing term including all four language skills and the development of communicative competence. Thus, practice in one skill should lead to the development of other skills (Skela 2002). This is more transparent in the first years of primary education, where the skills are integrated and the focus is on the development of learners' lis- 
tening and oral skills (Murphy 2014). Young learners are exposed to the spoken language through songs, stories and games. This early exposure to the language is essential in the process of reading and writing that comes later in their language acquisition. Furthermore, initial literacy includes the development of learners' phonological and phonemic awareness. Activities such as blending and manipulating sounds, noticing the onsets of words, breaking words into syllables and using rhymes help learners to decode words later in their reading development. According to Share (1999), phonological awareness is crucial for successful reading acquisition of all learners. Kormos and Smith (2012) go even further, claiming that it is crucial in the development of reading skills of learners with reading and writing difficulties.

In addition to phonological development, learners need to be exposed to a large amount of reading materials and be able to recognize words as whole to become efficient readers. This is the main rationale of the whole word or the whole language approach. The advocates of this approach claim that language is too unpredictable for rules, and context is crucial in developing meaning (Moats 2007). The English language is, a language with a lot of exceptions in rules and with its deep orthography can cause many problems to non-native readers, especially the ones whose native language has shallow orthography (Skela, Sešek and Dagarin Fojkar 2009; Cook 2016; Weaver 2002). Many authors, among them Brown (2007) and Geva and Ramírez (2015) claim that eclectic approaches produce better results in developing literacy, which has become known as 'interactive reading' in which readers continuously shift from predicting meaning to checking the meaning (Nuttall 2005). In varying the approaches, we need to constantly consider learner characteristics and contexts in which learning takes place (Hamayan 1994).

There are many reasons why reading strategies need to be developed in FL classes. Firstly, strategies present the process paradigm in literacy (Kern 2000). Furthermore, reading strategies, such as guessing meaning from context or using illustrations, can be transferable from one language to another, i.e. strategies used in the first language promote the same strategies used in another language and vice versa (Pinter 2017). Šamo (2009) compared the use of reading strategies among primary school learners and noticed that good readers used a variety of FL reading strategies and used them more frequently than weak readers. Similarly, Macaro and Mutton (2009) have argued that strategy instruction has beneficial effects on FL learning, basing their statement on research done with primary French learners, where the group exposed to the inferencing strategies outperformed the comparison groups in reading comprehension.

Writing is closely related to reading. For many learners it is perceived as the 
most difficult task in language learning and this is especially true for primary school learners, since writing requires many skills, among them organisation of thought, knowledge of content, proficiency in language, the ability to plan, revise, edit your own text, etc. (Reid 2001). Therefore, Cumming (2016) emphasises the importance of establishing routines for writing frequently and purposefully in a language classroom.

Among reading and writing activities commonly used in a primary classroom, Pinter (2017) mentions many games at word-level, phonics activities to reinforce regular patterns in English, gap-fill activities, multisensory activities, extensive reading, writing texts with the help of given models and reading as well as writing texts of different genres. These activities vary in difficulty with age and language level.

When planning reading and writing activities, Nuttall (2005) stresses the importance of selecting appropriate texts and mentions three main criteria in the choice: suitability of content (texts should be interesting and enjoyable for learners), exploitability (texts should offer opportunities for developing effective reading strategies) and readability (texts should be at the right level of structural and lexical difficulty). She further states that a variety of texts should be used in developing FL literacy.

Reading and writing activities can be done in many different types of grouping. While individual work seems to prevail in traditional classroom settings, research clearly shows that interactive writing tasks, when learners work together in pairs or groups, stimulate learning, and that students produce better texts than individually (Swain and Lapkin 1998).

Developing FL literacy skills entails many issues teachers need to take into account, such as choosing the right approach, activities, strategies, materials, types of texts, classroom organisation, etc. However, our primary concern should be providing students with authentic purposes for reading and writing in a foreign language.

\section{The Study}

The aim of the study was to investigate how English teachers develop foreign language literacy skills in grades $3-5$ in Slovenian primary schools, with the focus on developing reading and writing skills.

\section{Methodology}

A quantitative research approach was used. A questionnaire was constructed for the purpose of exploring teachers' practices in developing English reading and writing skills, i.e. strategies, activities and materials they use for de- 
veloping their students' literacy skills. The Delphi method was used to ensure the validity and reliability of the research instrument. First, a panel of international subject-matter experts and statisticians were asked to provide feedback on the questionnaire and how well the questions measure the construct. After the revisions, a pilot study was conducted using a sample of the population targeted. Teacher volunteers completed the questionnaire and provided information about two fundamental issues: the length of the questionnaire and the need for clarification of some of the questions included. The final version of the questionnaire was thus designed based on the structured rounds of revisions and covered sections such as: general information, reading and writing practices, reading resources, types of texts used in teaching and classroom organisation in developing reading and writing skills. Questions combined a descriptive 5-point rating scale and open questions. Respondents to the questionnaire were self-selected, as the online questionnaire was made available to all teachers of English through email, social media and personal contacts. The questionnaire was available on the website https://ww.1ka.si/ from December 2018 to March 2019.

Data was extracted from the web questionnaire and analysed with the SPSS programme. Results are presented in tables with calculated means and standard deviations. Furthermore, in some cases, inferential statistics was performed and differences between groups of teachers were calculated.

\section{Participants}

The questionnaire was completed by 111 English teachers who teach English in grades 3-5 in Slovenian primary schools. The minimum age of the participants was 24 years, the maximum age was 55 . The average age was therefore 36.01 years. As for the number of years working as a teacher, the minimum was 1 year, the maximum was 33 years and the average was 10.24 years.

Out of 111 participants there were 5 male (4.5\%) and 106 (95.5\%) female participants. 69 (61.6\%) participants were primary education teachers with specialisation in English, 3 participants (2.7\%) were primary education teachers and $33(29.5 \%)$ were English specialists. 80 (72.7\%) participants worked in the 3 rd grade, $67(60.9 \%)$ in the 4 th grade, and $64(58.2 \%)$ in the 5 th grade. The participants could teach in more than one grade, and therefore they had the option to choose more than one answer.

\section{Results and Discussion}

This part of the paper presents the main findings of the study linked to the main sections of the questionnaire, i.e. the activities used in the development 
Table 1 Activities for Developing Students' Reading Skills

\begin{tabular}{lrr}
\hline Item & $M$ & $S D$ \\
\hline Help students understand new vocabulary in the texts & 4.32 & 0.774 \\
Read aloud to the class & 3.98 & 0.849 \\
Do reading comprehension tasks orally & 3.90 & 0.880 \\
Listen to a tape while reading a text & 3.72 & 0.988 \\
Ask students to read aloud & 3.62 & 0.991 \\
Teach students strategies for decoding letters into sounds & 3.39 & 1.011 \\
Do reading comprehension tasks in writing & 3.31 & 1.139 \\
Ask students to read silently & 3.30 & 0.987 \\
Do a project about what they have read (e.g. a play or an art project) & 3.18 & 1.146 \\
Give students time to read books of their own choosing & 3.03 & 1.069 \\
Ask students to write something in response to what they have read & 2.64 & 1.263 \\
\hline
\end{tabular}

of reading skills, the development of reading strategies, the use of reading materials, types of texts used for reading, classroom organisation in the development of reading skills, the activities used in the development of writing skills and classroom organisation used in the development of writing skills.

\section{Developing Reading Skills}

In the first set of questions, teachers were asked which activities they use to develop their students' reading skills and how often (1 meant very rarely or never, 2 rarely, 3 occasionally, 4 frequently and 5 very frequently). As can be seen from table 1 , the most frequently used activity teachers use to develop their students' reading skills is helping them understand new vocabulary in the text, the second most frequent activity is reading aloud to the class, and the third one is doing reading comprehension tasks orally. The three topdown activities are asking students to write something in response to what they have read, giving students time to read books of their own choosing and doing a project about what they have read (e.g. a play or an art project). Halbach and Candel Bormann (2019) similarly noticed a lack of interest in literacy projects in primary schools around Madrid, and among the few projects that schools were involved in, only one or two were moving away from traditional teaching and towards the use of language in more meaningful contexts.

The teachers in the present survey could list other activities they use for developing their students' reading skills and among them they mentioned activities such as matching sentences with pictures, comparing Slovenian and English texts, different games practising sounds and syllables, and activities connected with rhythm, finding rhymes, finding words that begin/finish with 
Table 2 Activities for Developing Students' Reading Strategies

\begin{tabular}{lrr}
\hline Item & $M$ & $S D$ \\
\hline Find specific information in the text & 3.93 & 0.979 \\
Encourage risk taking and guessing about the text & 3.72 & 0.955 \\
Identify main ideas in the text & 3.60 & 1.086 \\
Make predictions about what will happen in the text & 3.45 & 1.089 \\
Compare what they have read with their experiences & 3.40 & 1.056 \\
Make generalisations and draw inferences based on the text & 3.34 & 1.083 \\
Talk about the text structure & 2.61 & 1.076 \\
Talk about the text genre & 2.38 & 1.104 \\
\hline
\end{tabular}

the same sound, reading books at home, and borrowing books from the library. This shows that teachers use a variety of activities for developing their students' reading skills.

A similar survey was conducted by Wray et al. (2000) where teachers had to state whether they use the following reading activities: teaching letter sounds/names, using cloze activities, using flashcards to teach particular words, using sequencing activities, reading to the class, using comprehension activities, using a big book with a group of children, involving other adults in reading with children, listening to children read/reading with children, using reading scheme books and using phonics exercises. The majority of teachers claim that they most often listen to children read or read with children (98.6), read to the class (97.6), involve other adults in reading with children (92.8) and teach letter sounds/names (92.1). Less than half of the teachers use comprehension activities (36.8), cloze activities (39.2) and flashcards (40.8) when teaching reading. Similar to our study, one of the most frequent activities that teachers use is reading aloud to the class. Contrary to our study, they rarely use comprehension activities, which are very common in developing students' reading skills in Slovenia.

Teachers were then asked how often and which activities they use to develop their students' reading strategies. As can be seen from table 2 , the most frequent activity teachers use for developing their students' reading strategies is finding specific information in the text. They also frequently encourage risk taking and guessing about the text and they ask students to identify the main ideas in the text. However, they rarely talk to students about text genre and text structure. They occasionally make generalisations and draw inferences based on the text. Some of the teachers also listed other activities they use for developing their students' reading strategies, some of which include summarising the text, completing the text with missing 
Table 3 Materials/Resources Used for Developing Students' Reading Skills

\begin{tabular}{lrr}
\hline Item & $M$ & $S D$ \\
\hline Worksheets & 3.77 & 0.931 \\
Children's books & 3.59 & 1.012 \\
Web pages & 3.27 & 1.035 \\
Graded readers & 3.26 & 1.093 \\
EFL textbooks & 3.21 & 1.555 \\
Materials written by students & 2.33 & 1.098 \\
Children's magazines & 2.28 & 1.063 \\
Non-fiction books & 2.21 & 1.037 \\
Materials from other subjects & 2.12 & 1.107 \\
CLIL textbooks & 1.48 & 0.989 \\
\hline
\end{tabular}

words, completing the text with their own ending, writing titles for different texts/paragraphs, learning about a step-by-step reading technique (reading the whole text first, finding the main idea, deciding/guessing what the paragraphs are about, stressing the main idea of the paragraph, finding answers in the text), etc.

Halbach and Candel Bormann's study (2019) similarly showed that teachers rarely talk about genres in developing literacy around the Madrid area and we believe this is the case in many FL educational contexts. Nevertheless, it is an important skill; when learners see language features of different text genres, it is much easier for them to produce their own texts of different genres (Ediger 2014).

We also wanted to find out how often and what kind of materials/resources teachers use for developing their students' reading skills. As is clear from table 3, for developing their students' reading skills teachers most frequently use worksheets. They also frequently use children's books and graded readers. Since we have very few CLIL schools, it is expected that the most rarely used materials are CLIL textbooks. There is also a lack of CLIL textbooks in Slovenia, which in turn leads to their non-use at schools. Teachers also rarely use materials from other subjects and non-fiction books. Some of them also stated other resources they use during their classes for developing their students' reading skills, e.g. different learning and movement games, their own/personal materials (appropriate for interactive white board), handouts they have created, short newspaper articles, online materials, EPI Reading Badge books, ${ }^{1}$ flashcards with words on one side, pictures that students have

${ }^{1}$ EPI Reading Badge is a national reading project where students read graded readers. 
Table 4 Texts Used for Developing Students' Reading Skills

\begin{tabular}{lrr}
\hline Item & $M$ & $S D$ \\
\hline Songs, chants & 3.92 & 0.916 \\
Dialogues/plays & 3.80 & 1.012 \\
Poems, riddles, limericks & 3.56 & 1.113 \\
Short stories, tales, fables & 3.29 & 1.107 \\
Charts, diagrams, graphs & 2.75 & 0.986 \\
Instructions or manuals about how things work & 2.17 & 1.135 \\
\hline
\end{tabular}

to transform into text, comic books, video clips, audio books, songs, etc.

A similar research was conducted in Maltese and Finnish schools (Sollars and Ylinen 2002), where significant differences were seen in the teachers' choice of materials/resources for developing their students' reading skills. Respondents could choose between the following reading resources used in schools: grammar books, storybooks, dictionaries, handouts, reference books, CD-ROMs, Internet, newspapers and magazines. Storybooks and handouts seem to be equally popular in both contexts, but there is a greater variety of materials used for reading activities in the Finnish classrooms, where they also frequently use dictionaries, reference books, grammar books and CD-ROM's. What is interesting to note among the Maltese respondents is the greater variety of reading material they claim to engage in at home with significant increases in the use of dictionaries, reference books, newspapers and magazines. Within the Finnish group, fewer children claim to use dictionaries, handouts, CD-ROM's and the Internet at home than at school. Similar to our study, the majority of Maltese and Finnish teachers also use children's books/story books and worksheets/handouts. However, the research does not offer the option to choose graded readers, which is common practice in Slovenia, so it is assumed they do not use them in Malta and Finland.

Slovenian respondents were also asked how often and what kinds of texts they use to develop their students' reading skills (table 4). The most frequently used are songs, chants, dialogues/plays and poems, riddles and limericks. Short stories, tales and fables are used less frequently. Charts, diagrams, and graphs as well as instructions or manuals about how things work are used the least frequently, which are common features of non-fiction texts. These data coincide with the data related to the types of resources used (table 3), where non-fiction texts were at the bottom of the list of the resources used. Some also listed other types of texts they regularly use for developing reading skills e.g. picture texts, short texts, tongue twisters, motivational quotes/sentences, grocery lists, greetings cards, announcements, comic 
Table 5 Classroom Organisation Used When Developing Students' Reading Skills

\begin{tabular}{lrr}
\hline Item & $M$ & $S D$ \\
\hline Whole-class & 4.09 & 0.793 \\
Pair-work & 3.66 & 0.855 \\
Individual work & 3.59 & 0.857 \\
Mixed-ability groups & 3.56 & 0.998 \\
Same-ability groups & 2.54 & 1.110 \\
\hline
\end{tabular}

books, picture books, short articles about relevant topics, brochures, menus, maps, fill-out forms, letters, etc.

Sollars and Ylinen (2002) report similar types of materials being used in Maltese and Finnish schools, where comprehension passages proved to be the most popular reading material in classrooms. Reading poems and letters appear to be almost equally popular activities in both schools. However, stories, articles, newspapers, magazines and recipes are much more frequently used in Finnish than in Maltese classrooms. Similar to our study, Maltese and Finnish schools frequently use poems/songs; however, there is no mention of dialogues and plays in their research, which are commonly used among Slovenian students.

Slovenian primary teachers were also asked which classroom organisation they most commonly employ when developing their students' reading skills. As can be seen in table 5, when developing their students' reading skills the most common classroom organisation is a whole-class form, followed by pair-work. Individual work and mixed-ability groups are also frequently used. The least used form is same-ability groups' organisation, indicating a possible lack of differentiation tasks in Slovenian classroom. Many authors stress the significance of group work in literacy development. Zhang (2018) emphasises the importance of peer reading in motivating FL learners to read. Nuttall (2005), similarly, supports reading in groups, by claiming that it is less threatening for learners than whole-class reading, and it provokes discussion among students on effective reading.

\section{Developing Writing Skills}

The study also investigated FL writing practices in Slovenian primary classrooms. Teachers were asked how often and which activities they use for developing their students' writing skills.

As can be seen in table 6, among given activities used for developing students' writing skills, gap-fills were most frequently used. Occasionally teachers use activities to practice spelling and copying. The least used activity 
Table 6 Most Common Activities Used for Developing Students' Writing Skills

\begin{tabular}{lrr}
\hline Item & $M$ & $S D$ \\
\hline Gap-fills & 3.45 & 1.003 \\
Activities to practice spelling & 3.24 & 1.064 \\
Copying & 3.13 & 0.963 \\
Creative writing & 2.64 & 1.244 \\
Writing texts of different genres (e.g. narratives, description ...) & 2.56 & 1.258 \\
Dictation & 2.15 & 1.097 \\
Summary writing & 2.06 & 1.149 \\
Writing non-fiction texts & 1.79 & 1.006 \\
\hline
\end{tabular}

was writing non-fiction texts. Summary writing and dictation are performed rarely. Teachers also suggested some other activities they use in order to develop their students' writing skills e.g. creative writing, made-up news, articles, descriptions about people, animals, objects, dialogues, mind maps, building sentences (out of random words), preparing stories in pairs, etc.

The lack of writing texts of different genres can be linked to the lack of reading texts of different genres (see table 1), as Brown (2007) states that by reading different texts, learners get an important insight into how they should write them. Primary FL course books mostly include short stories and comics, therefore learners might not get access to reading and writing different genres, among them also non-fiction texts, which is the activity that is employed in Slovenian primary FL classes the least. Summary writing, which is also very low on the list of writing activities above, is a very constructive way of developing learners' writing skills, since it employs many different skills, and seeing a text before writing your own one can help the learners with the topic of the text, its vocabulary and structure (Hirvela 2016). However, it is an activity that is usually not used in young learner classrooms extensively, as it requires a higher level of language competence.

In Wray et al's study (2000) teachers in Britain selected the following two writing activities as the most common: formation/handwriting (97.6\%) and writing for an audience other than the teacher ( $80 \%)$, but only a minority use peer group editing (12.8\%). Contrary to our study, the majority of teachers do not use spelling (66\%) and copying activities (52\%).

When it comes to Maltese and Finnish students, the most popular writing activity in their classrooms appears to be writing stories/compositions and letters. According to Sollars and Ylinen (2002), Maltese students are especially fond of writing poems and newspaper articles, which contributes to a statistically significant result between students of both nationalities, as writing po- 
Table 7 Classroom Organisation Used in Developing Students' Writing Skills

\begin{tabular}{lrr}
\hline Item & $M$ & $S D$ \\
\hline Individual work & 3.79 & 0.941 \\
Whole-class & 3.66 & 1.036 \\
Mixed-ability groups & 3.12 & 1.206 \\
Pair-work & 3.10 & 1.022 \\
Same-ability groups & 2.38 & 1.137 \\
\hline
\end{tabular}

ems and newspaper articles is rarely used in Finnish schools. Sollars and Ylinen (2002) further on state that this difference could be attributed to the fact that students of one of the Maltese schools are encouraged to submit contributions for the school publication/newspaper. It includes poems, letters, jokes, anecdotes, competitions and short stories. Contrary to our study, gapfill activities, activities where students practice spelling and copying, which are the most frequently used activities for developing students' writing skills in Slovenia, are not mentioned in the Maltese ${ }^{2}$ and Finnish research.

Slovenian primary teachers were also asked which classroom organisation they most commonly use when developing their students' writing skills. When developing their students' writing skills, the most often used form of class organisation is individual work. The least used form of class organisation in the case of developing writing skills is same-ability groups (table 7). There is some evidence that students' achievement also relates to effective classroom organisation. According to Pressley et al. (1996), the most effective classroom organisation is a combination of whole-class, group and individual teaching. A similar picture emerges from British research and suggests that effective teachers group children in their classrooms according to the children's needs and the tasks they are working on (Wray et al. 2000). Rarely used same-ability groups therefore imply lack of differentiation, which focuses on the success of each individual learner (Tomlinson 2014).

\section{Difference between Teachers' Years of Teaching Experience and Their Development of Students' Reading and Writing Skills}

Within the scope of the questions related to the difference between teachers' years of teaching experience and the way they develop their students' reading skills, statistically significant differences $(F=3.774, d f=2, p=0.026)$ were shown only in one answer i.e. how often teachers teach students strategies for decoding letters into sounds when they do (pre-, while-, post-) read-

\footnotetext{
${ }^{2}$ English is one of the two official languages in Malta, besides Maltese.
} 
Table 8 Difference between Teachers' Years of Working Experience and Their Development of Students' Decoding Strategies in Reading

\begin{tabular}{|c|c|c|c|c|c|c|c|c|}
\hline \multirow[t]{2}{*}{ Working years } & \multirow[t]{2}{*}{$N$} & \multirow[t]{2}{*}{$M$} & \multirow[t]{2}{*}{$S D$} & \multicolumn{2}{|c|}{ Levene test } & \multicolumn{3}{|c|}{ ANOVA } \\
\hline & & & & $F$ & $p$ & $F$ & $d f$ & $p$ \\
\hline $1-5$ & 45 & 3.27 & 1.095 & 2.059 & 0.133 & 3.774 & 2 & 0.026 \\
\hline $6-15$ & 34 & 3.76 & 0.855 & & & & & \\
\hline 16 and more & 30 & 3.13 & 0.973 & & & & & \\
\hline Total & 109 & 3.39 & 1.018 & & & & & \\
\hline
\end{tabular}

Table 9 Difference between Teachers' Years of Working Experience and the Classroom Organisation They Use When Developing Their Students' Writing Skills

\begin{tabular}{|c|c|c|c|c|c|c|c|c|}
\hline \multirow[t]{2}{*}{ Working years } & \multirow[t]{2}{*}{$N$} & \multirow[t]{2}{*}{$M$} & \multirow[t]{2}{*}{$S D$} & \multicolumn{2}{|c|}{ Levene test } & \multicolumn{3}{|c|}{ ANOVA } \\
\hline & & & & $F$ & $\bar{p}$ & $F$ & $d f$ & $p$ \\
\hline $1-5$ & 45 & 3.24 & 0.908 & 4.740 & 0.011 & 4.023 & 2 & 0.022 \\
\hline $6-15$ & 35 & 2.69 & 0.832 & & & & & \\
\hline 16 and more & 30 & 3.33 & 1.269 & & & & & \\
\hline Total & 110 & 3.09 & 1.028 & & & & & \\
\hline
\end{tabular}

ing activities with students (measured on the 5-point scale, 1 meaning very rarely or never, 2 rarely, 3 occasionally, 4 frequently and 5 very frequently). The Tukey HSD post hoc test showed that statistically significant differences were between teachers that had 6-15 years of working experience and the ones with more than 16 years of working experience. The ones that have 6-15 years working experience more often teach students strategies for decoding letters into sounds than the ones with more years of working experience.

With respect to questions regarding the development of students' writing skills, the only statistical significance between teachers with different years of working experience occurred with the question of classroom organisation that is used when developing students' writing skills, and only regarding pairwork ( $F=4.023, d f=2 / 76.656, p=0.022$ ). The Games Howell post hoc test showed statistically significant differences between teachers with 1-5 years of working experience and those with 6-15 years $(p=0.015)$. Those with less working experience use pair-work more frequently than the ones in the middle of their career.

\section{Conclusion}

Literacy in English as a foreign language should be developed systematically, through the development of all language skills, and it should start early on with a variety of approaches, activities and materials. 
The study, which focused on the development of FL literacy skills in grades 3-5 in Slovenian primary schools, has shown some positive practices and some challenges that need to be faced in the future. Teachers use a variety of activities in developing their students' reading skills. They focus on the development of their students' vocabulary and they often read aloud to them using children's books. They use a lot of songs, dialogues and poems in their teaching. In addition to that, they encourage the development of some reading strategies among their learners, risk taking and guessing about the text being the most often applied.

Some of the challenges that need to be considered in the future are listed below. The focus in the classroom is mostly on whole-class activities and individual work. Pair work and project work in developing literacy are not encouraged among learners, despite the fact that they are more motivating for students and, according to previous research, stimulate learning. The majority of reading activities focus on finding specific information in the text and students are not often given a choice to select what they want to read. In developing writing, there is still a considerable focus on activities that include imitative writing and gap-fills. Furthermore, non-fiction texts are not often used in primary classes, as well as materials from other subjects, which would invigorate cross-curricular links and more holistic learning. The excessive use of worksheets for developing writing can also be a cause for alarm, since they may not all be linguistically or developmentally appropriate for young learners and they do not encourage open-ended answers and creative thinking.

The findings of this study have to be seen in light of some limitations. A more comprehensive picture of the development of literacy would be established if we included longitudinal classroom observations, noting what is happening in the classrooms and how literacy is gradually developed in different grades. Moreover, interviews with teachers would show us a more in-depth analysis of their classroom practices and their concerns about developing their students' literacy skills, which we could then address more precisely in teacher education.

Nevertheless, we believe that this paper will serve teachers and teacher educators as a springboard to develop FL literacy more systematically and effectively, raising their awareness about the variety of texts, activities and classroom forms used in the process of developing FL literacy skills.

\section{References}

Baker, Colin. 2001. Foundations of Bilingual Education and Bilingualism. 3rd ed. Clevedon: Multilingual Matters. 
Brown, Douglas H. 2007. Teaching by Principles: An Interactive Approach to Language Pedagogy. 3rd ed. White Plains, NY: Pearson Education.

Cook, Vivian. 2016. Second Language Learning and Language Teaching. Oxon: Routledge.

Cumming, Alister. 2016. 'Writing Development and Instruction for English Language Learners.' In Handbook of Writing Research, 4th ed., edited by MacArthur, Charles A., Steve Graham, and Jill Fitzgerald, 364-76. New York: The Guilford Press.

Ediger, Anne. 2014. 'Teaching Children Literacy Skills in a Second Language.' In Teaching English as a Second or Foreign Language, 4th ed., edited by Marianne Celce-Murcia, 154-88. London: Heinle \& Heinle Thomson Learning.

European Commission. 2012. 'First European Survey on Language Competences: Final Report.' European Commission, Brussels.

Geva, Esther and Gloria Ramírez. 2015. Focus on Reading. Oxford: Oxford University Press.

Halbach, Ana and Daniel Candel Bormann. 2019. 'Inching towards Literacy in Madrid's Primary Schools: A Survey of School-Wide Projects.' Language and Education 33 (5) https://www.doi.org/10.1080/09500782.2019.1622712

Hamayan, Else. 1994. 'Language Development of Low-Literacy Students.' In Educating Second Language Children, edited by Fred Genesee, 278-300. Cambridge: Cambridge University Press.

Hirvela, Alan R. 2016. Connecting Reading \& Writing in Second Language Writing Instruction. 2nd ed. Ann Arbor, Ml: The University of Michigan Press.

Kern, Richard. 2000. Literacy and Language Teaching. Oxford: Oxford University Press.

Kormos, Judit, and Margaret A. Smith. 2012. Teaching Languages to Students with Specific Learning Difficulties. Clevedon: Multilingual Matters.

Leu, Donald J., Lisa Zawilinski, Jill Castek, Manju Banerjee, Brian C. Housand, Yingjie Liu, and Maureen O'Neil. 2007. 'What Is New about the New Literacies of Online Reading Comprehension?' In Secondary School Literacy, edited by Leslie S. Rush, A. Jonathan Eakle, and Allen Berger, 37-68. Denver, CO: National Council of Teachers of English.

Macaro, Ernesto, and Trevor Mutton. 2009. 'Developing Reading Achievement in Primary Learners of French: Inferencing Strategies versus Exposure to "Graded Readers."' Language Learning Journal 37 (2): 165-82.

Moats, Louisa. 2007. Whole-Language High Jinx: How to Tell When 'ScientificallyBased Reading Instruction'Isn't. Washington, DC: Thomas B. Fordham Foundation.

Murphy, Victoria A. 2014. Second Language Learning in the Early School Years: Trends and Contexts. Oxford: Oxford University Press.

Nuttall, Christine. 2005. Teaching Reading Skills in a Foreign Language. 2nd ed. Oxford: Heinemann. 
Pinter, Annamaria. 2017. Teaching Young Language Learners. Oxford: Oxford University Press.

Pressley, Michael, Joan Rankin, and Linda Yokoi. 1996. 'A Survey of Instructional Practices of Primary Teachers Nominated as Effective in Promoting Literacy.' Elementary School Journal 96 (4): 363-84.

Reid, Joy. 2001. 'Writing.' In The Cambridge Guide to Teaching English to Speakers of Other Languages, edited by Ronald Carter and David Nunan, 28-33. Cambridge: Cambridge University Press.

Share, David, L. 1999. 'Phonological Recoding and Orthographic Learning: A Direct Test of the Self-Teaching Hypothesis.' Journal of Experimental Child Psychology 72:95-129.

Skela, Janez. 2002. 'Multi-Literacy: Literacy Acquisition, (Creative) Reading and Writing in a Foreign and/or Second Language.' In Issues in Multi-Literacy, edited by Valerie Sollars. Strasbourg: Council of Europe.

Skela, Janez, Urška Sešek, and Mateja Dagarin Fojkar. 2009. 'Opismenjevanje v tujem/drugem jeziku na zgodnji stopnji.' In Učenje in poučevanje dodatnih jezikov $v$ otroštvu, edited by Karmen Pižorn, 220-45. Ljubljana: Zavod Republike Slovenije za šolstvo.

Sollars, Valerie and Ulla-Kaisa Ylinen. 2002. 'Young Learners' Reading and Writing Experiences of a Second/Foreign Language: The Maltese and Finnish Context.' In Issues in Multi-literacy, edited by Valerie Sollars, 135-71. Strasbourg: Council of Europe.

Stevenson, Marie. 2018. 'Learning Literacies.' In The Cambridge Guide to Learning English as a Second Language, edited by Anne Burns and Jack C. Richards, 242-50. Cambridge: Cambridge University Press.

Swain, Merrill, and Sharon Lapkin. 1998. 'Interaction and Second Language Learning: Two Adolescent French Immersion Students Working Together.' The Modern Language Journal 83:320-38.

Šamo, Renata. 2009. 'The Age Factor and L2 Reading Strategies.' In Early Learning of Modern Foreign Languages: Processes and Outcomes, edited by Marianne Nikolov, 121-31. Bristol: Multilingual Matters.

Tomlinson, Carol A. 2014. The Differentiated Classroom: Responding to the Needs of all Learners. Alexandria, VA: ASCD.

Weaver, Constance. 2002. Reading Process and Practice. 3rd ed. Portsmouth: Heinemann.

Wray, David, Jane Medwell, Richard Fox, and Louise Poulson. 2000. 'The Teaching Practices of Effective Teachers of Literacy.' Educational Review 52 (1): 75-84.

Zhang Jun, Lawrence. 2018. 'Learning Reading.' In Learning English as a Second Language, edited by Anne Burns and Jack C. Richards, 213-21. Cambridge: Cambridge University Press. 